\title{
ANALISIS RASIO KUALITAS AKTIVA PRODUKTIF, LIKUIDITAS DAN JATIDIRI KOPERASI SEHATI SMA NEGERI 4 PALEMBANG
}

\author{
Oleh: Zahruddin Hodsay \\ zhodsay@gmail.com \\ (Program Studi Pendidikan Akuntansi, FKIP Universitas PGRI Palembang)
}

\begin{abstract}
Abstrak-Tujuan dari penelitian adalah untuk mengetahui dan menganalisis rasio kualitas aktiva produktif, likuiditas dan jatidiri koperasi pada Koperasi Sehati SMA Negeri 4 Palembang. Metode penelitian yang digunakan yaitu metode kualitatif deskriftif. Teknik pengumpulan data adalah dokumentasi dan wawancara. Hasil penelitian menunjukkan bahwa berdasarkan rasio kualitas aktiva produktif menunjukkan bahwa selama 3 tahun jumlah pinjaman yang diberikan kepada anggota jauh lebih besar dibandingkan dengan pinjaman kepada selain anggota koperasi lainnya, separuh pinjaman yang diberikan merupakan pinjaman yang beresiko. Berdasarkan rasio likuiditas menunjukkan bahwa setiap kewajiban lancar sangat dijamin oleh kas, pinjaman yang diberikan sebesar 1 rupiah menghasilkan pendapatan sebesar 2-3 rupiah. Berdasarkan jati diri koperasi menunjukkan bahwa selama 3 tahun berturut-turut besarnya rasio partisipasi bruto capaiannya masih di bawah $50 \%$. Demikian juga untuk promosi ekonomi anggota pada tahun 2020 mengalami penurunan lebih dari $200 \%$ dibanding tahun sebelumnya.
\end{abstract}

Kata Kunci : Kualitas Aktiva Produktif, Likuiditas dan Jatidiri Koperasi

Abstract-The purpose of this research was to find out and analyze the ratio of the quality of productive assets, liquidity and cooperative identity in the cooperative to the Sehati State High School 4 Palembang. The research method used is a descriptive qualitative method. Data collection techniques are documentation and interviews. The results of the study show that based on the quality ratio of productive assets show that for 3 years the amount of loans given to members is far greater than loans to other than other cooperative members, half the loans given are loans at risk. Based on the liquidity ratio shows that every smooth liability is very guaranteed by cash, the loan given by 1 rupiah generates revenues of 2-3 rupiah2. Based on cooperative identity shows that for 3 consecutive years the gross participation ratio of its achievements is still below 50\%. Likewise for the economic promotion of members in 2020 decreased more than 200\% compared to the previous year.

Keywords: Quality of Productive Assets, Liquidity and Cooperative Identity

\section{PENDAHULUAN}

Koperasi adalah suatu badan usaha yang beranggotakan orang- orang atau badan hukum koperasi yang kegiatannya berlandaskan pada prinsip koperasi yang sekaligus 
sebagai gerakan ekonomi rakyat berdasarkan pada asas kekeluargaan. Dasar hukum dan kebijakan yang mengatur adanya perkoperasian sebagaimana yang terdapat dalam pasal 33 Undang-Undang Dasar 1945 dan Undang-Undang Nomor 25 Tahun 1992 tentang Perkoperasian (Indonesia, 1992)

Menurut (PSAK Nomor 27 tentang Perkoperasian, 2007), koperasi bisa dikelompokkan menjadi beberapa jenis koperasi, antara lain koperasi simpan pinjam, koperasi pemasaran, koperasi konsumen dan koperasi produsen. Pada prakteknya koperasi berada di berbagai tempat, baik kantor pemerintah, kantor perusahaan termasuk di lembaga pendidikan. Sekolah merupakan salah satu dari bentuk lembaga pendidikan, dimana koperasi juga dapat didirikan di sekolah tersebut.

Eksistensi koperasi dari masa ke masa dengan berbagai jenis yang berada di berbagai tempat sebagai soko guru ekonomi bangsa Indonesia, telah dapat berkontribusi yang signifikan dalam memberikan peningkatan kesejahteraan para anggotanya. Para anggota dapat terbantu dalam permasalahan finansial pribadi dan keluarga, baik untuk masa jangka pendek dan jangka menengah ataupun jangka panjang.

(Westriningsih, berpendapat bahwa koperasi sekolah adalah koperasi yang didirikan di lingkungan sekolah dengan beranggota murid-murid, yaitu didirikan di berbagai sekolah sesuai tingkatan atau jenjang pendidikan. Dengan demikian dapat dikatakan bahwa koperasi sekolah merupakan koperasi yang dibentuk dalam lingkungan sekolah, lembaga pendidikan formal ataupun non formal, yang beranggotakan warga sekolah antar lain guru, staf organisasi dan siswa.

Koperasi di sekolah yang ada umumnya berjenis koperasi simpan simpan, khususnya bagi guru dan staf di sekolah tesebut. Namun demikian banyak juga koperasi di sekolah berjenis koperasi lainnya seperti koperasi konsumen atau koperasi produsen.

Setiap akhir tahun setiap koperasi harus membuat laporan keuangan koperasi berupa Laporan Sisa Hasil Usaha (SHU) dan Neraca yang disampaikan dan dipertanggungjawabkan dalam Rapat Anggota Tahunan (RAT). Kewajiban tersebut biasanya diatur pada Anggaran Dasar (AD) serta Anggaran Rumah Tangga (ART) masing-masing koperasi. Dari laporan keuangan koperasi itulah dapat diketahui perkembangan kemajuan usaha koperasi, penambahan aktiva koperasi, posisi utang dan piutang koperasi, keuntungan yang diperoleh dan informasi penting lainnya.

Bila mengacu pada regulasi kebijakan terkait yang ada yaitu 
Peraturan Deputi Bidang Pengawasan Kemenkop dan UKM Nomor : 06/Per/Dep.6/2016 tentang Pedoman Penilaian Kesehatan Koperasi Simpan Pinjam dan Unit Simpan Pinjam Koperasi, menilai laporan keuangan koperasi dapat dilakukan analisis rasio untuk unit koperasi yang terbagi menjadi rasio efisiensi, rasio kualitas aktiva produktif, rasio permodalan, rasio likuiditas, rasio kemandirian dan pertumbuhan dan jati diri koperasi. (Indonesia R. , 2016)

Salah satu dari hasil penelitian tentang analisis rasio laporan keuangan koperasi seperti yang diungkapkan (Hodsay \& Yolanda, 2019) yang mengatakan bahwa dari keseluruhan aspek KSP Sejahtera SMK Muhammadiyah 2 Palembang pada tahun 2015 dengan skor 66,40 yang tergolong cukup sehat. Untuk tahun 2016 dengan skor 64,45 tergolong dalam kategori pengawasan dan tahun 2017 dengna skor 62,40 tergolong dalam kategori pengawasan.

Analisis rasio keuangan yang pada KSP Mitra Lestari Mataram membutktikan bahwa koperasi tersebut mempunyai kemampuan cukup baik untuk memenuhi kewajibannya, baik jangka panjang maupun jangka pendek. Berdasarkan penilaian kesehatan koperasi menunjukan bahwa KSP Mitra lestari Mataram termasuk katagori koperasi sehat karena dengan ditunjukan nilai skor yang diproleh 84,19 (Karyawan, 2015).

Berdasarkan dari berbagai latar belakang di atas, maka peneliti ingin melakukan penelitian dosen tentang "Analisis Rasio Kualitas Aktiva Produktif, Likuiditas dan Jatidiri Koperasi pada Koperasi Sehati SMA Negeri 4 Palembang".

Selanjutnya rumusan masalah yang akan diungkapkan dalam penelitian ini adalah bagaimanakah rasio kualitas aktiva produktif, likuiditas dan jatidiri koperasi pada Koperasi Sehati SMA Negeri 4 Palembang?.

Penelitian inu bertujuan untuk mengetahui dan menganalisis rasio kualitas aktiva produktif, likuiditas dan jatidiri koperasi pada Koperasi Sehati SMA Negeri 4 Palembang.

Pada penelitian kali ini ditargetkan dapat memberikan partisipasi atau manfaat bagi berbagai pihak. Bagi pengelola koperasi sekolah, dari hasil penelitian ini diharapkan memberikan bahan masukan dalam meningkatkan peran koperasi sekolah dalam meningkatkan kesejahteraaan anggota dan pengelolaan koperasi pada masa yang akan datang. Sedangkan bagi anggota koperasi, diharapkan hasil penelitian ini nanti memberikan informasi tentang perkembangan usaha koperasi melalui kualitas aktiva produktif, likuiditas dan jatidiri. Terakhir bagi peneliti lain, 
dapat menjadi bahan referensi dan perbandingan yang berguna dalam melakukan penelitian variabel sejenis pada masa selanjutnya.

\section{METODE PENELITIAN}

(Sugiono,

menyampaikan bahwa metode penelitian adalah cara ilmiah guna mendapat data dengan tujuan dan kegunaan tertentu. Sedangkan pendapat lainnya (Arikunto, 2013) mengungkapkan bahwa metode penelitian merupakan cara yang digunakan oleh peneliti untuk mengumpulkan data penelitiannya. Pada penelitian ini metode penelitian yang digunakan yaitu metode kualitatif deskriftif.

(Nazir, 2014) menyampaikan bahwa metode deskriftif adalah suatu metode dalam penelitian yang meneliti status sekelompok manusia, suatu objek, suatu kondisi, suatu sistem pemikiran, atau juga suatu kelas peristiwa yang terjadi pada masa sekarang. Tujuan dari penelitian deskriftif ini untuk membuat deskripsi, gambaran atau lukisan secara sistematis, faktual dan akurat tentang fakta-fakta, sifat-sifat serta hubungan antar fenomena yang diselidiki. Pendapat lainnya diungkapkan bahwa penelitian kualitatif merupakan metode penelitian yang temuannya tidak diperoleh melalui prosedur kuantifikasi dan perhitungan statistik, atau bentuk cara-cara lainnya dengan menggunakan angka (Gunawan, 2015).

Untuk mencari data dan informasi penelitian yang diperlukan maka digunakan teknik pengumpulan data sebagai berikut:

a. Dokumentasi

Dokumentasi adalah upaya mencari data, seputar hal-hal atau variabel berupa catatan, surat kabar, buku, transkrip, majalah, prasasti, notulen rapat, legger agenda dan sebagainya (Arikunto, 2013).

Teknik ini peneliti digunakan untuk mendapatkan data Neraca dan Laporan Sisa Hasil Usaha (SHU) untuk tahun 2018, 2019 dan 2020 koperasi Sehati SMA Negeri 4 Palembang, Data ini merupakan data sekunder.

b. Wawancara

Menurut Esterberg dalam (Sugiono, 2019) mendefinisikan interview sebagai berikut. "a meeting of two persons to exhange information and idea through question and responses, resulting in communication and joint construction of meaning abaout a particular topic". Maksudnya adalah wawancara merupakan pertemuan dua orang untuk bertukar informasi dan ide melalui tanya jawab, sehingga akhirnya dapat dikonstruksikan makna dalam suatu topik tertentu.

Pada penelitian ini, wawancara dilakukan pada pengurus koperasi dan perwakilan anggota untuk 
mengetahui proses pengelolaan koperasi sekolah di SMA Negeri 4 Palembang selama 3 tahun berturut. Wawancara ini digunakan sebagai data pendukung.

Pada penelitian ini, untuk mengolah data peneliti menggunakan teknik analisis data kualitatif. Menurut (Sugiono, 2019) yang dimaksud analisis data kualitatif merupakan proses untuk memilih, memilah serta mengorganisasikan data yang terkumpul yang berasal dari catatan lapangan, hasil observasi, wawancara mendalam dan dokumentasi sampai diperoleh pemahaman yang mendalam, bermakna, unik dan temuan baru bersifat deskriptif.

Analisis kualitatif peneliti gunakan untuk menganalisis rasio kualitas aktiva produktif, likuiditas dan jatidiri koperasi pada Koperasi Sehati SMA Negeri 4 Palembang,

\section{HASIL DAN PEMBAHASAN}

Untuk menganalisis rasio kualitas aktiva produktif, likuiditas dan jatidiri koperasi pada Koperasi Sehati SMA Negeri 4 Palembang menggunakan formula (rumus) sebagaimana yang terdapat pada Peraturan Deputi Bidang Pengawasan Kemenkop dan UKM Republik Indonesia Nomor : 06/PER/DEP.6/IV/2016 tentang Pedoman Penilaian Kesehatan KSP dan USP Koperasi. Setelah dilakukan perhitungan menggunakan rumus tersebut, selanjutnya hasil perhitungannya dilakukan konfirmasi dengan standar yang ada kemudian peneliti melakukan analisis rasio tersebut untuk 3 tahun dari laporan keuangan koperasi yaitu tahun 2018, 2019 dan 2020.

\section{Rasio Kualitas Aktiva Produktif}

a. Rasio volume pinjaman pada anggota terhadap pinjaman yang diberikan, dengan rumus :

Volume pinjaman pada anggota $\times 100 \%$ Volume Pinjam an

Berdasarkan data laporan keuangan koperasi, diketahui volume pinjaman pada anggota Rp 18.027.270,- (2018), Rp 13.320.000,- (2019) dan Rp 13.795.000,- (2020). Sedangkan volume pinjaman $\mathrm{Rp} 20.721 .00$,(2018), Rp 14.800.000,- (2019) dan Rp 15.500.000,- (2020).

Hasil perhitungan menunjukkan sebesar $87 \%$ untuk tahun 2018. Pada tahun berikutnya 2019 mengalami kenaikan sebesar $90 \%$, namun mengalami sedikit penurunan pada tahun 2020 sebesar $89 \%$. Dengan demikian selama 3 tahun jumlah pinjaman yang disalurkan kepada anggota jauh lebih besar dari jumlah pinjaman pada koperasi, dengan kata lain dana koperasi diperuntukkan lebih banyak pinjaman kepada anggota dibandingkan dengan pinjaman kepada selain anggota, koperasi lainnya, surat hutang dan sejenisnya. 
b. Rasio resiko pinjaman bermasalah terhadap pinjaman yang diberikan, dengan rumus : Pinjaman bermasalah

Pinjam an yang diberikan $\times 100 \%$

Dari data laporan keuangan koperasi Sehati SMAN 4 Palembang diketahui bahwa pinjaman bermasalah sebesar $\mathrm{Rp}$ 2.270.000,- $\quad$ (2018), $\quad \mathrm{Rp}$ 1.560.400,- (2019) dan Rp 1.278.000,- (2020). Selanjutnya untuk pinjaman yang diberikan $\mathrm{Rp}$ 20.721.00,- $\quad$ (2018), $\quad \mathrm{Rp}$ 14.800.000,- (2019) dan Rp 15.500.000,- (2020).

Berdasarkan hasil perhitungan data di atas, maka diketahui rasio ini pada tahun 2018 sebesar 10,96 \%, tahun 2019 sebesar 10,54\% dan tahun 2020 sebesar 8,25 \%. Hal ini membuktikan bahwa resiko pinjaman bermasalah dari tahun ke tahun mengalami penurunan yang signifikan, sehingga resiko atas pinjaman yang kemungkinan macet atau tak tertagih dapat ditekan. Oleh karena itu berdasarkan ketentuan penilaian Permenkop UKM 06/2016 di atas, dikategorikan "pinjaman kurang lancar".

c. Rasio cadangan resiko terhadap pinjaman bermasalah

Perhitungan rasio cadangan resiko terhadap pinjaman yang bermasalah tidak dapat dilakukan simulasi perhitungan karena pada laporan keuangan koperasi Sehati di SMA Negeri 4 Palembang tidak dialokasikan cadangan resiko. Adapun cadangan resiko merupan cadangan tujuan resiko yang ditambah penyisihan penghapusan pinjaman. Cadangan resiko dimaksud juga untuk menutupi resiko apabila terjadi pinjaman macet atau dengan kata lain tak tertagih.

d. Rasio Pinjaman yang Beresiko terhadap Pinjaman yang diberikan, dengan rumus :

$\frac{\text { Pinjaman yang beresiko }}{\text { Pinjam an yang diberikan }} \times 100 \%$

Berdasarkan data yang terdapat pada laporan keuangan koperasi Sehati SMAN 4 Palembang, diketahu pinjaman yang beresiko sebesar Rp 10.000.000,- (2018), Rp 7.250.000,(2019) dan Rp 7.800.000,- (2020). Sedangkan pinjaman yang diberikan sebesar Rp 20.721.00,- (2018), Rp 14.800.000,- (2019) dan $\mathrm{Rp}$ 15.500.000,- (2020).

Dengan menghitung rasio tersebut menggunakan rumus di atas, diperoleh rasio pinjaman yang beresiko terhadap pinjaman yang diberikan pada tahun 2018 sebesar 48,26\%, tahun 2019 sebesar 48,96 $\%$ dan tahun 2020 sebesar 50,32\%. Hal ini artinya dari tahun ke tahun besarnya persentase pinjaman yang beresiko mengalami kenaikan, walaupun tingkat kenaikannya tidak signifikan. Dengan demikian dapat disimpulkan bahwa separuh pinjaman yang diberikan merupakan pinjaman yang beresiko. 


\section{Rasio Likuiditas}

a. Rasio Kas, dihitung dengan menggunakan rumus :

$\frac{\text { Kas }}{\text { Kewajiban Lancar }} \times 100 \%$

Dari laporan keuangan koperasi Sehati SMAN 4 Palembang, diketahui Kas untuk tahun 2018 sebesar Rp 68.849.400,-, untuk tahun 2019 sebesar Rp 87.550.000,- dan untuk tahun 2020 sebesar Rp 70.494.000,-. . Sedangkan untuk kewjiban lancar untuk tahun 2018 sebesar Rp 12.000.000,-, untuk tahun 2019 sebesar Rp 11.250.000,- dan untuk tahun 2020 sebesar Rp 9.500.000,-.

Setelah dilakukan perhitungan diketahui rasio kas tahun 2018 sebesar 573,75 \%, tahun 2019 sebesar 778,22 \% dan tahun 2020 sebesar 742,04 \%. Hal ini bermakna setiap kewajiban lancar sangat dijamin oleh kas, atau dengan kata lain sekalipun kewajiban lancar jatuh tempo makan dapat dilakukan pelunasan dengan menggunakan kas tanpa mengganggu saldo kas yang berarti. Karena setiap 1 rupiah kewajiban lancar dijamin oleh 5,7 rupiah kas untuk tahun 2018, setiap 1 rupiah dari kewajiban lancar dijamin oleh 7,8 rupiah kas untuk tahun 2019 dan setiap 1 rupiah dari kewajiban lancar dijamin oleh 7,4 rupiah kas untuk tahun 2020.

b. Rasio volume pinjaman terhadap pana yang diterima, dihitung dengan menggunakan rumus : $\frac{\text { Pinjam an yang diberikan }}{\text { Dana yang diterima }} \times 100 \%$

Bila memperhatikan laporan keuangan koperasi Sehati SMAN 4 Palembang, besarnya pinjaman yang diberikan pada tahun 2018 sebesar Rp 20.7210.000,-, pada tahun 2019 sebesar Rp 14.800.000,- dan pada tahun 2020 sebesar Rp 15.500.000,-. Sementara itu besarnya dana yang diterima tahun 2018 sebesar Rp 72.165.000,-, tahun 2019 sebesar Rp 84.714.000,- dan tahun 2020 sebesar Rp 55.105.000,-

Berdasarkan hasil perhitungan rasio volume pinjaman terhadap dana yang diterima menggunakan rumus di atas, diperoleh rasio tahun 2018 sebesar 28,71\%, tahun 2019 sebesar $17,47 \%$ dan tahun 2020 sebesar $28,12 \%$. Jika dibandingkan rasio tahun 2018 dan 2019 mengalami penurunan, namun pada tahun 2020 mengalami peningkatan kembali. Dengan demikian dapat disimpulkan bahwa dari pinjaman yang diberikan tahun 2018 sebesar 1 rupiah menghasilkan pendapatan sebesar 2,9 (dibulatkan 3) rupiah, sedangkan pinjaman yang diberikan tahun 2019 sebesar 1 rupiah menghasilkan pendapatan sebesar 1,8 (dibulatkan 2) rupiah. Terakhir untuk pinjaman yang diberikan pada tahun 2020 sebesar 1 rupiah menghasilkan pendapatan sebesar 2,8 (dibulatkan 3) rupiah.

\section{Jati Diri Koperasi}

a. Rasio partisipasi bruto, dihitung dengan menggunakan rumus : 
$\frac{\text { Partisipasi Bruto }}{\text { Partisipasi Bruto + Pendapatan }} \times 100 \%$

Berdasarkan laporan keuangan koperasi Sehati SMAN 4 Palembang diketahui bahwa partisipasi bruto untuk tahun 2018 sebesar Rp 9.424.000,-, untuk tahun 2019 sebesar Rp 30.090.000,- dan untuk tahun 2020 sebesar Rp 6.340.000,-Selanjutnya partisipasi bruto ditambah pendapatan pada tahun 2018 sebesar Rp 27.518.000,-, pada tahun 2019 sebesar Rp 66.710.000,dan pada tahun 2020 sebesar Rp 35.560.000,-.

Bila dilakukan perhitungan menggunakan rumus di atas, maka didapat rasio partisipasi bruto sebesar 34,25\% untuk tahun 2018. Sedangkan untuk tahun 2019 sebesar $45,11 \%$ dan untuk tahun 2020 sebesar $17,83 \%$. Sebagaimana kita ketahui rasio partisipasi bruto merupakan tingkat kemampuan koperasi untuk melayani anggota, maka semakin tinggi/besar persentasenya semakin baik. Selama 3 tahun berturut-turut besarnya rasio partisipasi bruto,capaiannya masih dibawah $50 \%$, bahkan untuk tahun 2020 mengalami penurunan yang cukup signifikan. Hal ini tidak menutup kemungkinan merupakan imbas dari adanya kondisi pandemic covid-19 sejak awal tahun 2020 yang telah merontokkan sendi-sendi ekonomi masyarakat, karena berdasarkan analisis informasi wawancara bahwa pandemic covid19 juga memberikan dampak terhadap pendapatan dan keuntungan koperasi.

b. Rasio promosi ekonomi anggota (PEA), dihitung dengan menggunakan rumus :

$\frac{\text { PEA }}{\text { Simpanan Pokok + Simpanan Wajib }} \times 100 \%$
Promosi Ekonomi Anggota (PEA) adalah manfaat Ekonomi Partisipasi Pemanfaatan Pelayanan (MEPPP) ditambah manfaat SHU. Manfaat MEPPP merupakan manfaat yang bersifat ekonomi yang diperoleh anggota maupun calon anggota pada saat bertransaksi dengan koperasi. Selanjutnya manfaat Sisa Hasil Usaha (SHU) merupakan bagian anggota yang diperoleh setahun sekali berdasar pada perhitungan pasrtisipasi anggota setelah memanfaatkan pelayanan koperasi.

Dengan memperhatikan laporan keuangan koperasi Sehati SMAN 4 Palembang dapat diketahui bahwa Promosi Ekonomi Anggota (PEA) tahun 2018 sebesar Rp 8.010.400,-, tahun 2019 sebesar Rp 25.576.500,- dan untuk tahun 2020 sebesar Rp 5.389.000,-. Kemudian untuk simpanan pokok ditambah simpanan wajib pada tahun 2018 sebesar Rp 46.200.000,-, tahun 2019 sebesar Rp 65.640.000,- dan tahun 2020 sebesar Rp 36.400.000,-.

Setelah dilakukan perhitungan berdasar rumus di atas, maka dapat diketahui rasio promosi ekonomi anggota pada tahun 2018 sebesar 17,34 \%, pada tahun 2019 sebesar 
$38,96 \%$ dan pada tahun 2020 sebesar $14,80 \%$. Jika dilihat pada tahun 2019 mengalami kenaikan lebih dari $200 \%$ dibandingkan dengan tahun sebelumnya 2018, namun pada tahun 2020 mengalami penurunan cukup tajam. Permasalahan ini juga diperkuat berdasar analisis informasi wawancara peneliti bahwa pandemi covid-19 ikut memberikan pengaruh terhadap besar kecilnya sisa hasil usaha (SHU) yang diperoleh oleh koperasi.

\section{KESIMPULAN}

Beranjak dari hasil penelitian dan pembahasan tersebut di atas, dapat dibuat kesimpulan antara lain :

a. Berdasarkan rasio kualitas aktiva produktif menunjukkan bahwa selama 3 tahun jumlah pinjaman yang disalurkan terhadap anggota jauh lebih besar disbanding dengan pinjaman kepada selain anggota, koperasi lainnya, dan sejenisnya. Selain itu diketahui juga bahwa separuh pinjaman yang diberikan adalah pinjaman yang beresiko.

b. Berdasarkan rasio likuiditas menunjukkan bahwa setiap kewajiban lancar sangat dijamin oleh kas, sekalipun kewajiban lancar jatuh tempo makan dapat dilakukan pelunasan dengan menggunakan kas tanpa mengganggu saldo kas yang berarti. Pinjaman yang diberikan sebesar 1 rupiah menghasilkan pendapatan sebesar 2-3 rupiah.

c. Berdasarkan jati diri koperasi menunjukkan bahwa selama 3 tahun berturut-turut besarnya rasio partisipasi bruto, capaiannya masih dibawah $50 \%$, Hal ini kemungkinan merupakan imbas dari adanya pandemic Covid-19 yang terjadi mulai awal tahun 2020 lalu. Demikian juga untuk promosi ekonomi anggota pada tahun 2020 mengalami penurunan lebih dari $200 \%$ dibanding tahun sebelumnya.

Mengacu dari hasil penelitian tersebut di atas, peneliti mempunyai saran yaitu :

a. Bagi pengelola koperasi, disarankan agar dapat lebih meningkatkan semangat dan kinerja dalam mengelola koperasi agar usaha, pendapatan dan SHU kembali normal setelah pandemo covid-19 berlalu.

b. Bagi anggota koperasi, disarankan agar tetap berpartisipasi aktif sebagai anggota koperasi dengan melaksanakan hak dan kewajibannya dengan baik, diantaranya adalah melakukan pengembalian pinjakan secara teratur.

c. Bagi peneliti lainnya, disarankan agar dapat melakukan penelitian lanjutan yang terkait dampak pandemic covid-19 terhadap tingkat kesehatan koprasi yang mana hasil penelitian itu nanti 
dapat menjadi referensi penelitian.

\section{DAFTAR PUSTAKA}

Arikunto, S. (2013). Prosedur Penelitian Suatu Pendekatan Praktik. Jakarta: Rineka Cipta.

Gunawan, I. (2015). Metode Penelitian Kualitatif, Teori dan Praktek. Jakarta: Bumi Aksara.

Hodsay, Z., \& Yolanda, Z. (2019, November Sunday). Analisis Penilaian Kesehatan Keuangan Koperasi Simpan Pinjam (KSP) Sejahtera SMK Muhammadiyah 2 Palembang. Profit, 6, 1141125.

Indonesia. (1992). Undang-Undang Republik Indonesia Nomor 25 tentang Perkoperasian. Jakarta: Republik Indonesia.

Indonesia, I. A. (2007). PSAK Nomor 27 tentang Perkoperasian. Jakarta: Ikatan Akuntan Indonesia.

Indonesia, R. (2016). Peraturan Kementerian Kopeasi dan Usaha Kecil dan Menengah Nomor 06/Per/Dep.6/2016 tentang Pedoman Penilaian Kesehatan Koperasi Simpan Pinjam dan Unit Simpan Pinjam Koperasi. Jakarta: Kementerian Koperasi dan UKM.

Karyawan, I. N. (2015). Penilaian Kesehatan dan Rasio Keuangan Koperasi Simpan Pinjam Mitra Lestari Mataram. 9(2), 36 - 41.

Nazir, M. (2014). Metode Penelitian. Bogor: Ghalia Putra.
Sugiono. (2015). Metode Penelitian Pendidkan Pendekatan Kuantitatif, Kualitatif dan $R$ \& D. Bandung: Alfabeta.

Sugiono. (2019). Metode Penelitian Pendidikan (Kuantitatif, Kualitatif, Kombinasi, $R \& D$ dan Penelitian Pendidikan). Bandung: Alfabeta.

Westriningsih. (2018). Koperasi Sekolah. Jakarta: Cempaka Putih. 